Article

\title{
The Impact of Tourism Activity on Coastal Biodiversity: A Case Study at Praia da Cova Redonda (Algarve-Portugal)
}

\author{
Leonel J. R. Nunes ${ }^{1,2, *\left(\mathbb{C} \text {, Mauro A. M. Raposo }{ }^{2}(\mathbb{D}) \text { and Carlos J. Pinto Gomes }\right.}{ }^{2,3(1)}$ \\ 1 proMetheus-Unidade de Investigação em Materiais, Energia e Ambiente para a Sustentabilidade, \\ Escola Superior Agrária, Instituto Politécnico de Viana do Castelo, Rua da Escola Industrial e Comercial \\ de Nun'Alvares, 4900-347 Viana do Castelo, Portugal \\ 2 MED-Mediterranean Institute for Agriculture, Environment and Development, Pólo da Mitra, \\ Universidade de Évora, 7006-554 Évora, Portugal; mraposo@uevora.pt (M.A.M.R.); \\ cpgomes@uevora.pt (C.J.P.G.) \\ 3 Departamento da Paisagem, Ambiente e Ordenamento, Universidade de Évora, 7000-671 Évora, Portugal \\ * Correspondence: leonelnunes@esa.ipvc.pt; Tel.: +351-258-909-740
}

Received: 3 September 2020; Accepted: 9 October 2020; Published: 12 October 2020

\begin{abstract}
Tourism activity has a very significant weight in the world economy, even being the main activity responsible for the export of many countries, in the form of providing services to foreign citizens. In mainland Portugal, the main tourist region is the Algarve, where beach tourism, known as sun and sea tourism, plays a decisive role. However, this activity also has its negative impacts. In the present work, a case study was analyzed, at Praia da Cova Redonda, located in the parish of Porches, in the municipality of Lagoa. Negative impacts on land use and occupation were identified, caused by the excessive presence of people, the introduction of invasive species and the artificial filling of beaches. At the end, a set of mitigating measures are presented that aim to ensure that the exploitation of natural resources can be maintained, but in a perspective of preservation and recovery of natural resources and biodiversity.
\end{abstract}

Keywords: coastal ecosystems; biodiversity; environmental impacts; mitigation measures

\section{Introduction}

The tourism industry significantly impacts the world economy, contributing to the creation and maintenance of millions of jobs and being responsible for many billions of euros to the economies of many countries [1,2]. Currently, worldwide, just a few countries do not allow tourism activity, and when, for some reason, this activity is interrupted, as is the case of the COVID-19 pandemic crisis, in an attempt to reduce the transmission of the virus, with the vast majority of countries closing their borders, an immediate impact was observed on tourism economy by preventing the movement of people [3]. This was one of the major concerns demonstrated by all heads of state, as soon as it was possible to resume the circulation of people, countries attempted to show that they are safe destinations to attract as many tourists as possible, and thus, helping the economic recovery, with tourism working as the driving force [4-7].

Given the importance of the tourism economic and social impact, it is necessary to characterize it from an environmental perspective as well, since the sustainability of the sector can only be achieved by attaining a balance between the three pillars, namely, the economic, social and environmental [8]. Since it is an activity where a large number of people temporarily move and settle in a certain place, pressuring local resources, such as drinking water availability, waste production or energy consumption, tourism can impact negatively the regions where it occurs [9-12]. Coastal regions have attracted the 
greatest number of tourists, since tourism became a recurring activity [13]. Initially, by medical advice populations living far from the sea were advised to spend seasons enjoying the sea air and baths [14]. The exposure to sunlight, congregated with some physical activity, hitherto practically non-existent, and a richer diet in sea products, contributed to the improvement in the health of the populations, leading to a generalization of beach tourism [15].

However, this accumulation, normally seasonal, of people in a given location is due to the aspects mentioned above, necessitating a strengthening in the capacity, for example, of wastewater and sewage systems, supply chains of the food service and hotel industries, solid urban waste management systems and of the energy and fuel supply networks [16]. In addition to these problems, a number of other problems are directly related to environmental aspects, such as landscape management and land use, with the protection of ecosystems and biodiversity, or with the anthropogenization of natural spaces and their artificialization [17-20].

The tourism industry is one of the activities that is expected to suffer profound impacts with climate change [21]. This new reality will affect all environmental variables of the ecosystems, changing their dynamics and balances. Thus, understanding the relationships between the different parts in a given ecosystem is essential [22-24]. It is already well known that regions that will be most affected by climate change are those with a Mediterranean climate, where Algarve is included. This situation related to climate change, just for itself, justifies the deepening of knowledge about environmental impacts that tourism can cause or increase. In mainland Portugal, the most important touristic region is Algarve, which received approximately 3 million overnight stays during the month of August in prepandemic years, assigning tourism, therefore, an important role in the local economy [25,26]. However, the entire region feels the environmental weight of the tourism activity, mainly due to the tourism activity and load being unevenly distributed throughout the year, with particular incidence during spring and summer, forcing an over-dimensioning of the infrastructure and an additional effort to satisfy the needs of all who visit the region, as visitors usually have a different attitude toward consumption and waste since a vacation is often associated with the two $[25,27,28]$.

Algarve includes a number of locations of particular interest in terms of the natural environment, which are widely known and already subject to special protection regulations, such as Ria Formosa Natural Park, Costa Vicentina and Southwest Alentejo Natural Park, or Castro Marim and Vila Real de Santo António Wetland Natural Reserve, or even those classified under Habitats Directive sites, such as Arade/Odelouca, Ria de Alvor, Barrocal or Ribeira de Quarteira. For example, locations like Monchique or Caldeirão, present several exclusive endemism with particular interest for biodiversity preservation. However, a wider range of other areas are also of interest for preservation, mainly because they host important native flora and fauna communities, some of which are extremely rare, and therefore more fragile given the increasing urban pressure caused by the growing demand for new spaces for the tourism industry, for the development of its projects and for increased capacity to receive visitors closer to the environment that need to be protected [29-31].

An example of species that were thought to have disappeared from the national territory is Carrichtera annua (L.) DC. of the Brassicaceae family, rediscovered in 2019 in Cerro da Águia in the municipality of Albufeira. It is a species that saw its preferred habitat occupied, firstly, by the urban expansion and, later, by invasive species, widely used in gardening, such as Oxalis pes-caprae L., which is more aggressive and more adaptable, so the South African invader won the competition. Figure 1 shows one of the first specimens identified and the overlap of Carrichtera annua (L.) DC. territory with those of other species. This area of the Algarve includes the municipality of Lagoa, part of the municipality of Silves, with the parish of Armação de Pêra, and the municipality of Albufeira, which includes some of the landscapes most sought after by tourists, with small beaches, embedded in steep cliffs, composed of limestone rocks from the Miocene period that create idyllic scenery and provide dreamy views. In other words, the landscape is a resource to be exploited, which increases pressure on the other components of the landscape, such as biodiversity. Therefore, the analysis and 
assessment of environmental impacts are urgent, so that mitigating and corrective measures can be implemented [32].

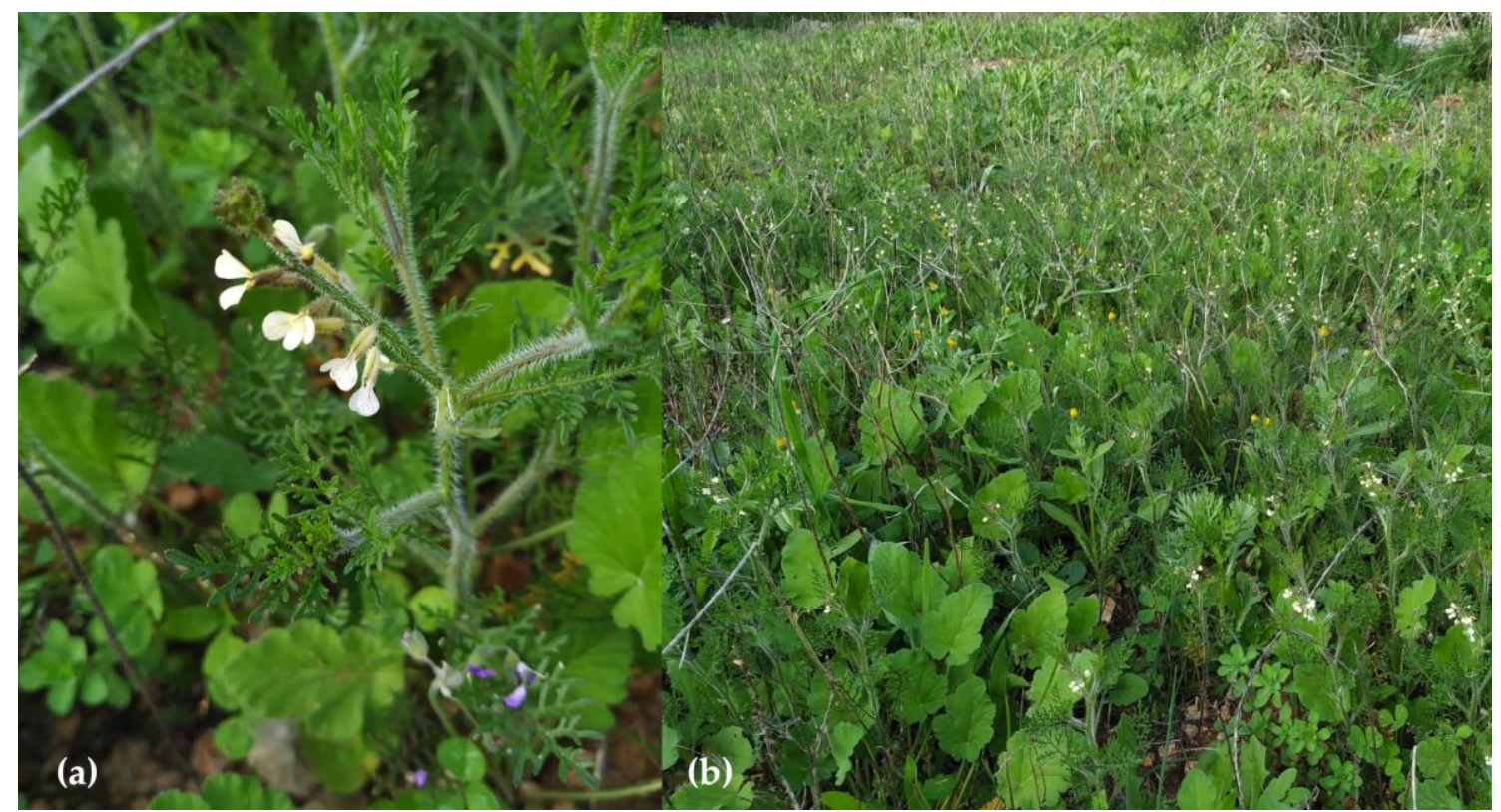

Figure 1. (a) Specimens of Carrichtera annua (L.) DC. identified during spring 2019 and photographed in 2020 in the town of Cerro da Águia, in Albufeira, by Mauro Raposo, researcher at the Mediterranean Institute for Agriculture, Environment and Development (MED). (b) Group of plants of different species, with emphasis on the specimens of Carrichtera annua (L.) DC.

In this study, the information was collected over a long period of observations at the site, which began in 2005 and continued uninterruptedly until 2020. In this 15-year period, the development of flora and fauna was observed at the site and all urban development. Bibliographic research was used to complement the information and provide points of comparison with data collected in other studies carried out in similar situations, such as the studies conducted by Teixeira (2016) or by Pinto et al. (2020) for situations related to the artificial filling of beaches [33,34]; or the studies by Brunel et al. (2010), Marchante et al. (2014), Carapeto (2016) or by Campoy et al. (2018) for situations related to invasive plant species [35-38]; or studies by Russo et al. (2020), Varelas et al. (2020) or by Sousa et al. (2020) for situations related to the environmental impacts associated with the tourism industry [39-41]; or even the studies presented by Bienvenido-Huertas et al. (2020), Sá Marques et al. (2020) or by Cavaco and Costa (2020) for situations related to land use [42-44]. In addition to these references, databases available in www.turismodoalgarve.pt, www.ine.pt and www.pordata.pt were consulted as well.

The information collected in the form of observation notes on landmarks considered relevant for different fauna communities, with a particular emphasis on the growing population of seagulls, but mainly with regard to flora communities, from which the microforests of native species stand out, initially abundant in the place, and which have seen, over the years, their space being occupied by invasive alien species. Underwater marine fauna was observed in a casual, non-systematic way, through filming and photo shooting sessions in specific locations, selected for the abundance of marine life and the ease of access, which were repeated over the years, and which allowed to evaluate the populations status. All notes and observations taken over the years, in a naturalistic perspective of the study of the evolution of the natural environment, have not been published. These observations led to the assessment of a set of negative impacts, which are outlined in Figure 2, and where the trends of occurrence over time are pointed out, and where they are associated with processes of development of the tourism industry, namely with the accentuation of the development of new ventures in the region. 


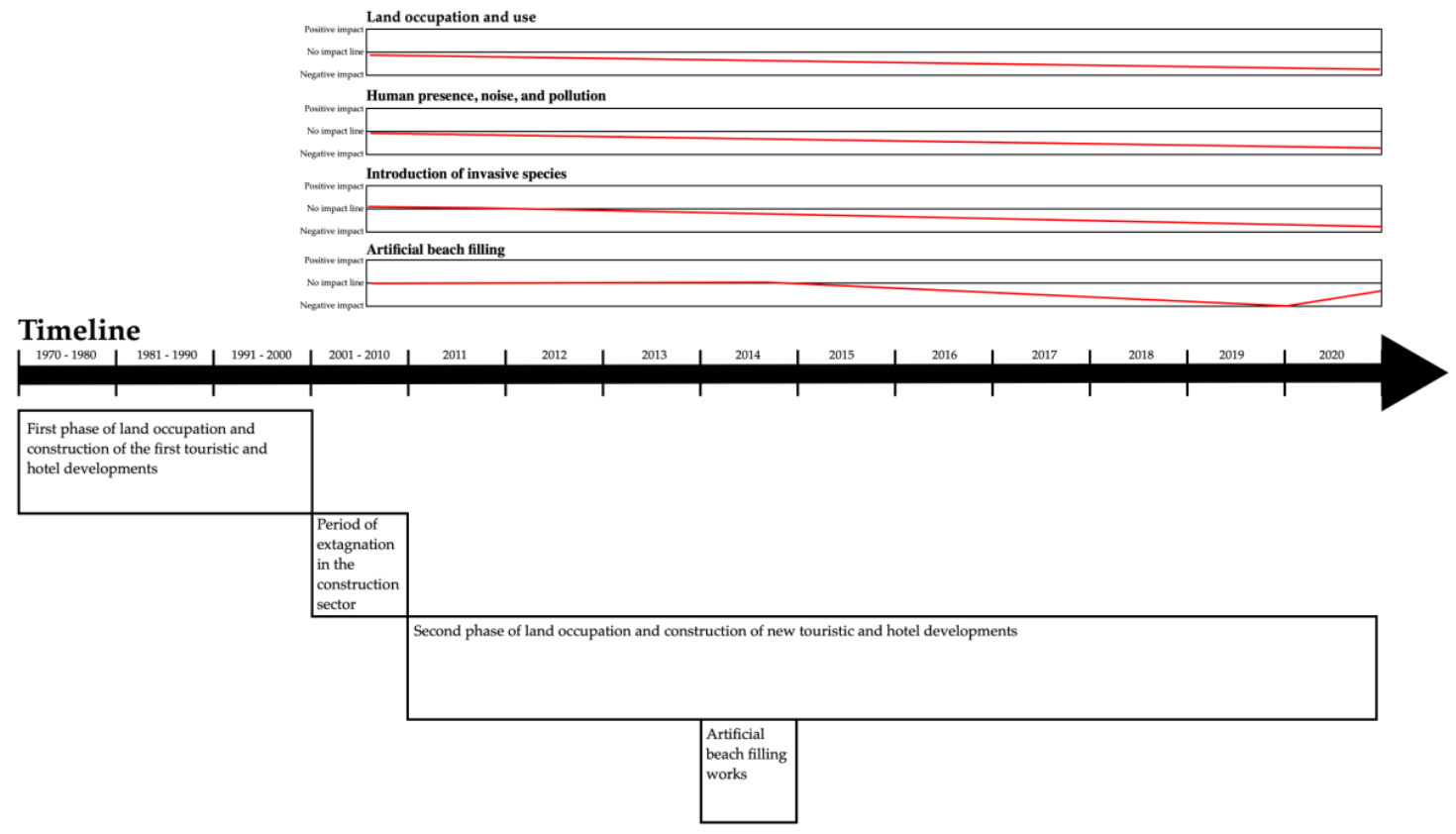

Figure 2. Definition of the main environmental impacts observed and the trend of the evolution of these impacts over time, with the identification of the main periods of occurrence of the stages of development of civil construction in the area under study.

The main objective of this study was to review the main impacts in a natural environment related to the tourism industry in coastal areas, using a target area as a reference, selected as an example where several of these impacts are combined and where the pressure on the natural resources is high. As a corollary of this work, a set of mitigating and restoration measures of the natural space are presented to emphasize the protection of biodiversity and the recovery of ecosystems.

\section{Study Framework}

\subsection{State-of-the-Art Research}

Many diverse studies can be found about the environmental impacts of the tourism industry, including analyses of the diverse types of impacts, in all sets of ecosystems, with all groups of species. Examples including pioneering studies carried out by Raschke (1970), who made the first allusions to the assessment of the environmental impact of the tourism industry as being the path to the sector's sustainability [45], or the work of Yusoff and Hashim (1970), who assessed the environmental impacts in Malaysia, when the country started to be a sought-after destination, mainly for beach tourism, but also for the beginning of adventure tourism [46]. Another important study was Haulot et al. (1977), who assessed the impacts related to tourism in coastal areas [47].

More recently, Travis (1982) and Inskeep (1987) focused on environmental management in terms of the tourism industry, with particular emphasis on planning the use of natural resources and physical spaces [48,49]. Romeril (1989) emphasized the importance of the environmental dimension in the development of the tourism industry and the inclusion of the perspective of sustainability [50]. Meanwhile, studies focusing on specific locations began to appear. For example, Liu and Var (1986) studied the impacts of tourism in Hawaii [51]; and Holder (1988) analyzed the impacts in the Caribbean region [52].

With the advent of ecotourism in the final phase of the last century, studies emerged that were no longer limited to the non-destruction of the natural environment, but rather to its maintenance in its purest and untouched state [53]. 
Currently, many researchers are focusing on the preservation of biodiversity, since it is seen as a resource that can and should be valued. Canteiro et al. (2018) [54], Ellison (2018) [55], Setyaningrum et al. (2019) [56], Costa and Zalmon (2019) [57] and da Costa Cristiano et al. (2020) [58] focused on preserving biodiversity and restoring ecosystems. This perspective of natural space management has contributed to the protection of biodiversity. However, it only does so due to its capacity to generate wealth. In other words, it is not a true intention to preserve the natural space and biodiversity, but rather is only a way of using a resource, and interest in its preservation may be lost if there is no longer a market interested in its use and/or usufruct.

Additionally, many recent studies have addressed the negative impacts of conflictive use of coastal areas, such as the study presented by Mateus et al. (2016), where it deals with a case study in Ria de Alvor, a coastal lagoon located near the area under study in the present work [59]. Harik et al. (2017) presented a study where they compared the application of a vulnerability index based on biodiversity versus the shoreline environmental sensitivity index to management and policy planning in coastal areas [60], while Cavallaro et al. (2017) presented a study on measures to mitigate the emission of greenhouse gases (GHGs) caused by mass-tourism mobility in coastal areas [61]. More recently, Kovačić and Silveira (2020) presented the results of a study on the implications and impacts of cruise tourism in Mediterranean areas such as Portugal and Croatia [62]. From the perspective of the stakeholders in the tourism industry, Pereira et al. (2020) presented a study on their perceptions on global trends in coastal areas of the Mediterranean region [63]. However, the policy instrument at the European level, the Habitat Directive for the conservation and protection of biodiversity, and the promotion of the use of natural resources remains to be added to the numerous studies carried out to date to guarantee its long-term preservation. In this perspective, there are several works carried out, such as the studies by Sousa et al. (2020), Rebelo et al. (2016), Blau et al. (2018) or Pallero et al. (2018) [41,64-66].

In the field of tourism, there is an increase in the number of studies related to the impact of climate change [67] due to the economic significance of the activity for an increasing number of countries [68]. However, these works, like those by Friedrich et al. (2020) or Enríquez and Bestard (2020), only examined the economic impacts of climate change on tourism $[22,69]$.

\subsection{Characterization of the Target Area of Study}

\subsubsection{Location and Framework}

The Cova Redonda beach is located in the parish of Porches, the municipality of Lagoa, in the Western Algarve. It is one of the most emblematic beaches in this region where some of the most renowned touristic resorts are located, which have long been sought by national and international tourists (Figure 3). The area began its development in the 1980s with the construction of the first large-scale hotel, which still maintains activity. The construction of a set of urban developments followed, which now occupy almost the entire area available in the vicinity of the existing beaches on the site: Praia Nova and Praia dos Pescadores. This urban development practically eliminated the original houses belonging to the local community, which was displaced inland, leaving the space for the development of tourism projects. However, in Praia dos Pescadores, fishing activity continues, albeit on a small scale and artisanal type, but which continues to supply fresh fish and seafood to local restaurants, contributing to the proximity economic cycle, and guaranteeing the resident population paid activity outside the months of intense tourist activity. Currently, the area is consolidated and there are not many spaces available for the development of large urbanization projects.

\subsubsection{Climatic and Oceanographic Framework}

The region under study, and the whole of the Algarve, has a Mediterranean Pluviseasonal-Oceanic bioclimatic with a thermomediterranean thermoclimate and a semi-arid ombroclimate according to the classification presented by Rivas-Martinez et al. (2017) [70]. In other words, the climate is typical Mediterranean, with dry summers and mild winters, with rainfall distributed between September 
and May, mainly concentrated between October and April, with the highest pick in December, reaching values higher than $100 \mathrm{~mm}$. The months of June to August are normally months of drought, and the months of May and September are months of transition between the rainy and dry seasons. The average temperature of the air reached its maximum values in the months of July and August, around $32^{\circ} \mathrm{C}$. The mildness of the climate is confirmed by the mild average minimum temperature, which is around $6{ }^{\circ} \mathrm{C}$ in January.

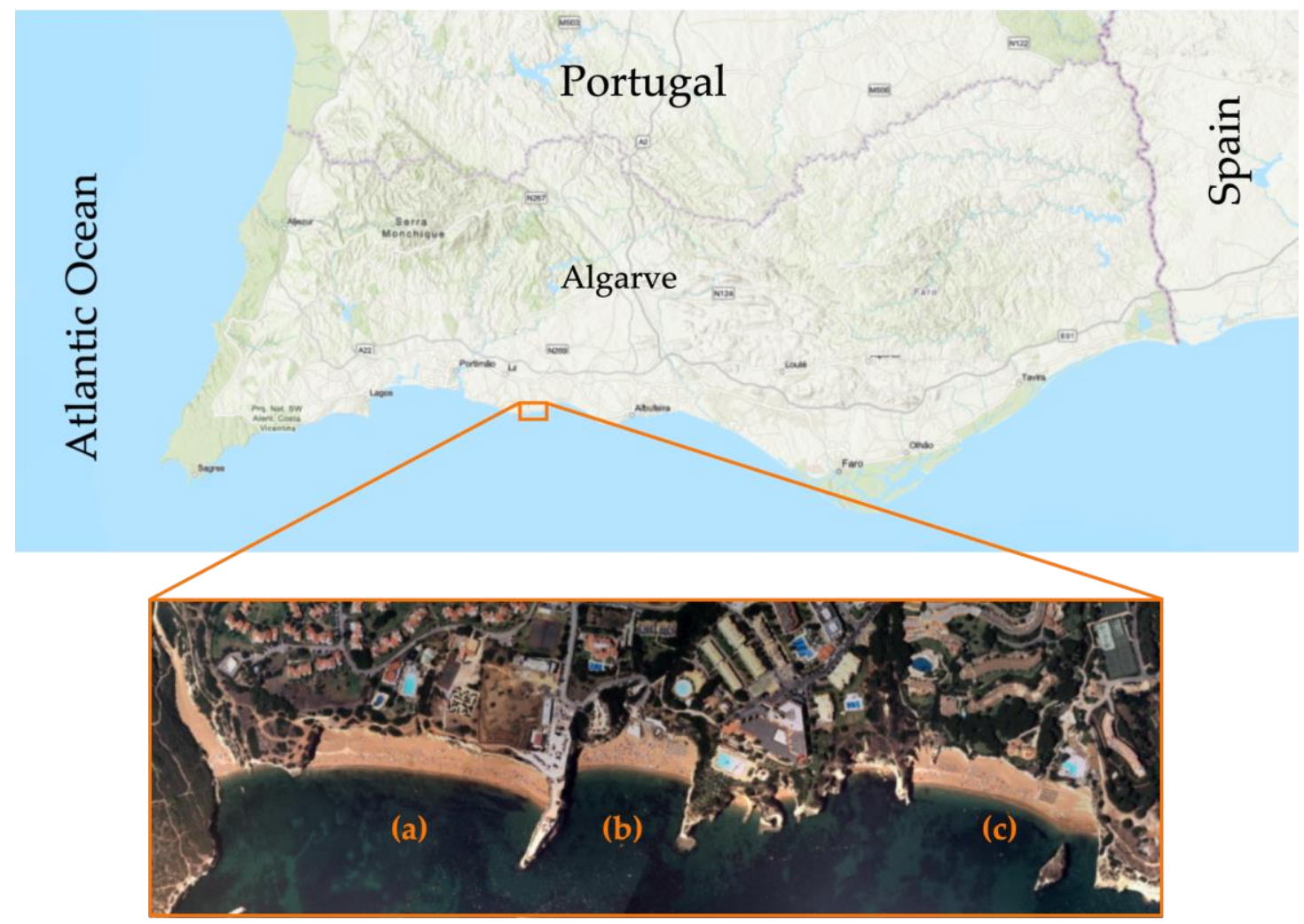

Figure 3. Location of the area in study: (a) Praia Nova, (b) Praia dos Pescadores and (c) Praia da Cova Redonda.

The maritime agitation regime is considered moderate, with an average wave height of $1 \mathrm{~m}$. The undulation is bimodal, with a predominance of the west and southwest quadrant directions. The east and southeast quadrants are associated with the east wind, locally called Levante. This dissymmetry of the course of the sea agitation results in a coastal drift from west to east. The tide has a semidiurnal regime with an average tidal range of $2 \mathrm{~m} \mathrm{[71].}$

\subsubsection{Geomorphology and Geology}

Praia da Cova Redonda stretches for approximately $235 \mathrm{~m}$, surrounded by a cliff that can reach about $18 \mathrm{~m}$ in height. The sand can vary between 30 and $70 \mathrm{~m}$ depending on the tide and the morphosedimentary dynamics throughout the year, with a slope that can vary between $5^{\circ}$ and $8^{\circ}$. At its eastern end, there is a natural point about $70 \mathrm{~m}$ in length that functions as a natural jetty (Figure 4).

From a geological viewpoint, the entire structure consists of overlapping carbonated rocks from the Miocene, encompassed in the Lagos-Portimão carbonated formation, mainly by the intercalation of soft, yellowish-colored limestones with sandy, also light-colored limestones, where they proliferated abundant macro fossils [72]. At the top of the structure, a sedimentary structure is visible, consisting of red, clastic and consolidated plioplistocene sediments [73]. Figure 5 shows the overlap of the carbonated strata and the marks of the different heights of the sea level, with the clastic sediments at the top of the rock column where the vegetation grows. 


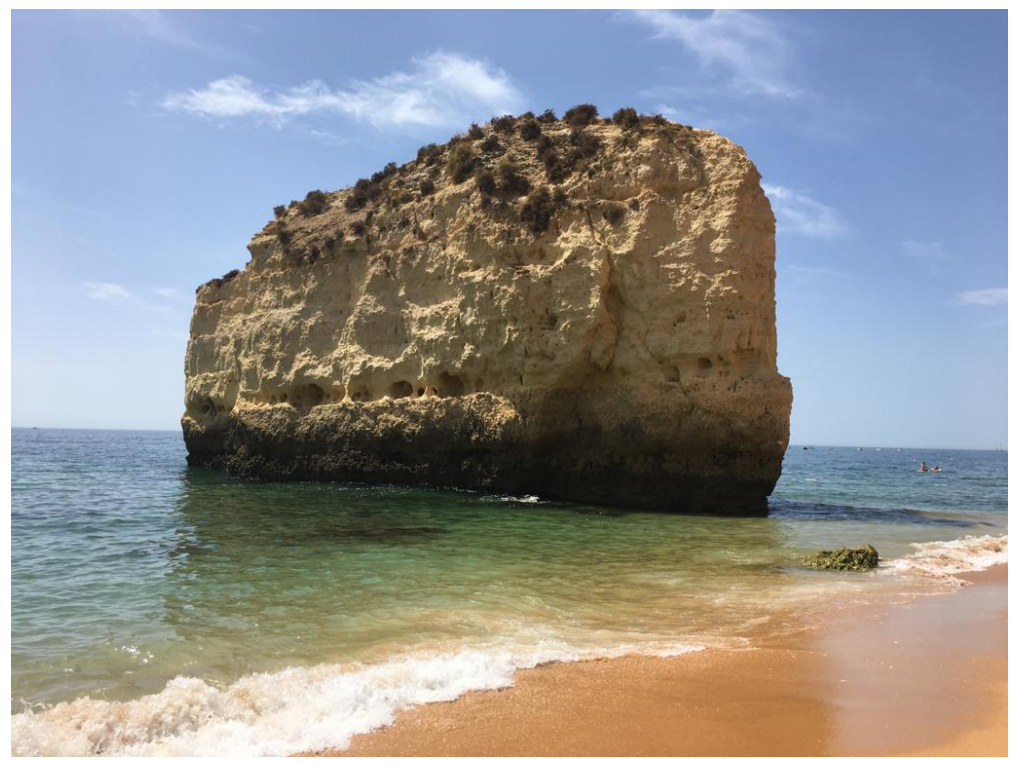

Figure 4. Aspect of the east end of Praia da Cova Redonda.

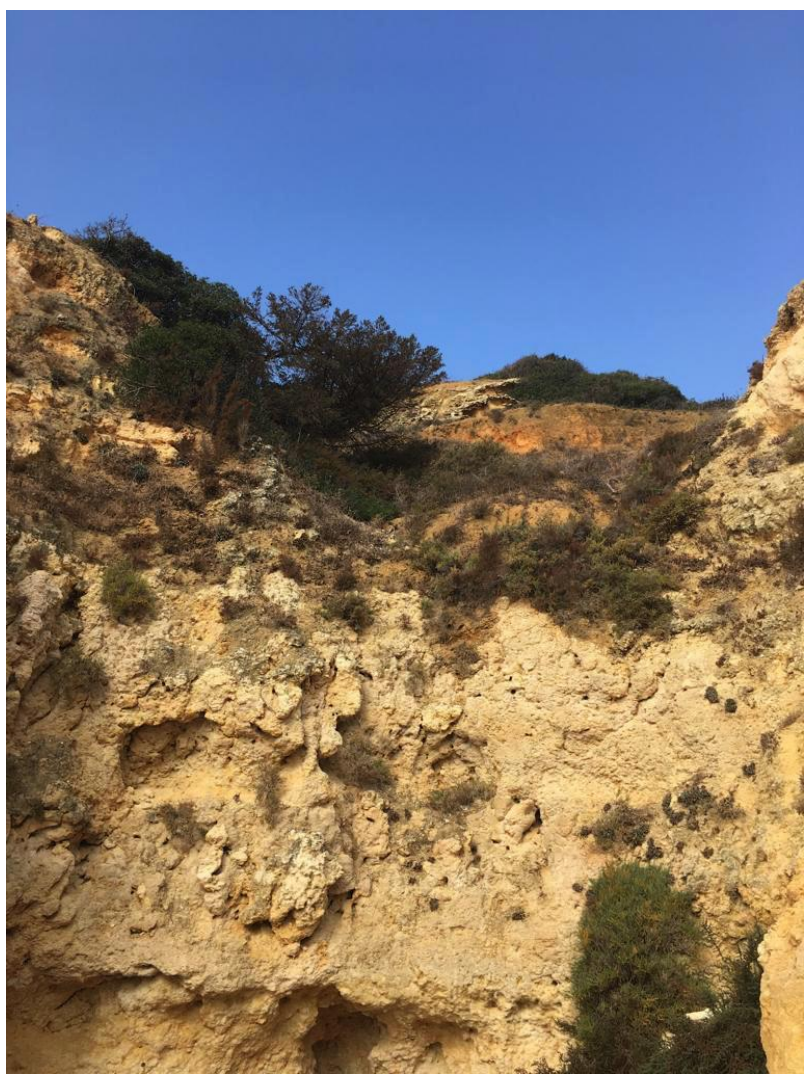

Figure 5. Overlapping carbonate strata and clastic sediments.

\subsubsection{Potential Natural Vegetation}

The coastal cliffs in Algarve have poorly developed vegetation cover due to the edaphoclimatic limitations, with special emphasis on the action of the wind associated with the dissection of plants by sea salt. Human action on these cliffs is secular, which has contributed to the strong degradation of the natural vegetation associated with the urban-touristic pressure of the last decades [74].

A large part of the Algarve coastline consists of microforests of Juniperus turbinate Guss. from the phytosociological association of Querco cocciferae-Juniperetum turbinatae [75]. In a position further 
from the cliffs, there are still some scattered specimens of stone pine (Pinus pinea L.), possibly a stronghold of a natural forest [74]. In this type of habitat, the only native palm of the Iberian Peninsula, the dwarf palm (Chamaerops humilis L.), has high ornamental value [75]. However, with the destruction of these climatic formations, a set of replacement shrub communities appeared dominated by Atriplex halimus L., Pistacia lentiscus L., Rhamnus lycioides subs. oleoides (L.) Jahand. and Maire and Phlomis purpurea L. [74]. In places of the most anthropogenic action, replacement communities furthest from mature vegetation appeared, consisting of small herbaceous and shrubs, such as Thymbra capitata $\mathrm{L}$. (Cav.), Frankenia laevis L., Crithmum maritimum L. and Thymus lotocephalus G. López and R. Morales, some of which have a high ornamental value [75].

\section{Negative Environmental Impacts}

\subsection{Land Occupation and Use}

Since the 1970s and 1980s, the entire area surrounding Praia da Cova Redonda has been subjected to intense urbanization, with the construction of several large hotel units, followed by numerous urban housing projects for short-term rentals and second homes, usually for tourist purposes. This construction first occupied the lands closest to the sea, with privileged views over the cliffs without a safety margin and completely outside the current construction standards. At the beginning of this development period, the main objective was to quickly attract the largest number of tourists and take advantage of this flourishing opportunity, with the municipalities facilitating civil construction at this time.

This unrestrained growth led to the continuous occupation of the soil with the destruction of the traditional vegetation cover, leaving only a few remnants of that occupation in some isolated areas that are difficult to access, like islands on land confined by the limits of the properties of hotels or condominiums. This occupation and alteration of land use led to a profound change, for example, in the flows of rainwater runoff, and to the exponential increase in the impermeable areas, which had significant and direct negative impacts on the vegetation covering these soils, resulting in soil loss. Currently, the remnants of this traditional vegetation cover still flourishes in isolated areas; its disappearance or thinning is anticipated. As observed by M. Raposo in 2018 and 2019 (unpublished observations), Carrichtera annua (L.) DC. had its space reduced and occupied by other more aggressive alien invasive species and more adapted to the new reality of climate change, such as Oxalis pes-caprae L., and was considered extinct for many years, until a small community was rediscovered in the municipality of Albufeira, as previously mentioned, or to the changes imposed on the soil by the artificial remediation required for the survival and flourishing of ornamental species.

\subsection{Human Presence, Noise and Pollution}

The excessive seasonal presence of people on Cova Redonda beach, as well as on the other beaches in the region, profoundly impacted the coastal ecosystem, directly interfering with wild species. The cliffs that surround the beach are the refuge of several species of birds, such as seagulls like the silver gull (Larus michahellis (Naumann, 1840)), which nests and lives here. Adult birds and their young are commonly seen roaming the sand, as they are accustomed to human presence and interaction, approaching to collect food scraps from holidaymakers (Figure 6). The interactions between people and animals are so common that many of these seagulls feed mostly on the remains left on the beach and by looting nearby garbage containers. There are reports, collected from habitual users of the beach and lifeguards, describing the aggressive behavior of seagulls, who try at all costs to obtain food, especially near young children, resulting, occasionally, in minor injuries and in a big scare. In the hotel units on site, signs are posted asking guests not to feed the birds as they land directly on the tables of the terraces of restaurants and bars in search of food, ignoring the presence of people.

The excessive numbers of people do not only interact with wild animals on the sand, but this also extends to the marine environment. If the use of the water for bathing can be considered a minor impact that can be neglected, the continual circulation of motorboats and jet skis is an impact that 
has to be considered, since they cause discomfort to the space users. The negative impacts associated with recreational boats include noise, constant agitation of the water, shock to animals and pollution by hydrocarbons, as stated by Whitfield and Becker (2014) and Sim et al. (2015) [76,77]. However, perhaps the most important negative impact is the permanent intrusion of tourist transport boats in the hundreds of small rocky coves, caves and other many similar formations in the region of Algarve [78]. Since these places are of difficult or impossible access by land, they have become places of refuge, protection and shelter for wildlife (Figure 7).

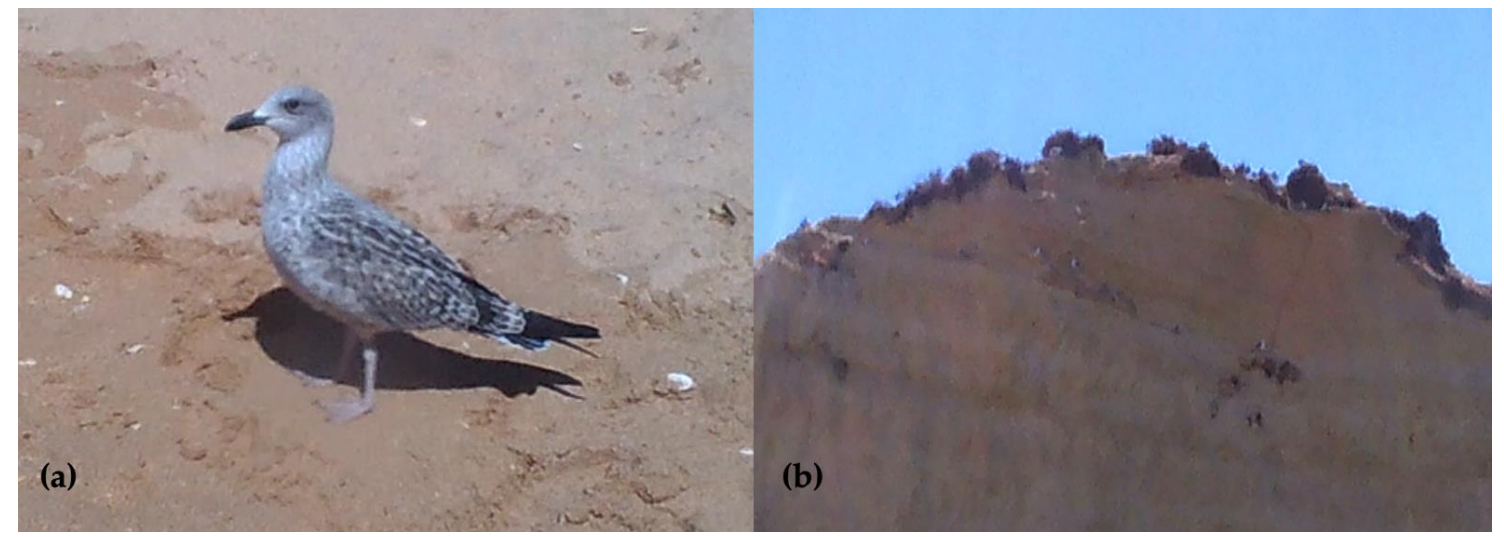

Figure 6. (a) Juvenile specimen of Larus michahellis (Naumann, 1840). (b) Nesting areas in the cliffs.

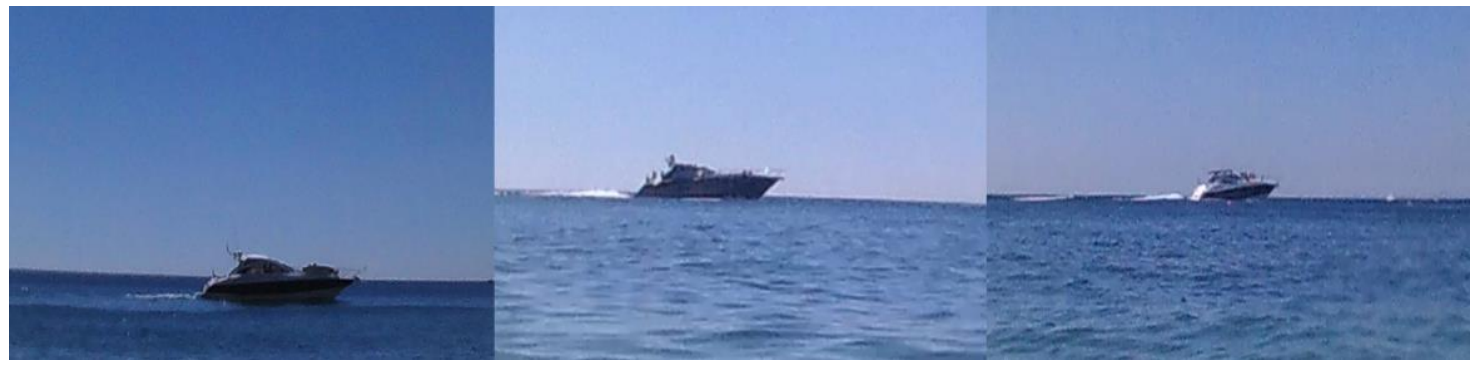

Figure 7. Continuous flow of pleasure boats and tourist transportation for visiting the caves along the rocky coast of Lagoa, Silves and Albufeira. These three vessels were photographed within $5 \mathrm{~min}$, moving at great speed and less than $100 \mathrm{~m}$ from the beach, making the engine noise very audible.

This continuous invasion by sea disturbs wildlife by causing unrest in the communities, changing their habits, and, thereby, their normal development [79]. This intensive seasonal occupation occurs after a period where there are no disturbances when the bathing tourist activity practically disappears in the autumn and winter months [80]. However, when resumed with the arrival of spring and summer, it coincides precisely with the reproduction period of a large number of resident species, which use these areas for breeding, and are therefore disturbed [81-83].

\subsection{Introduction of Invasive Species}

Land occupation in this area was not limited to the construction of tourist resorts and housing developments; the landscape organization of the site included the creation of extensive landscaped areas that are part of the built complexes, which contributed to the destruction of the typical Mediterranean native flora that is currently only found in small portions of land [84]. These areas are at permanent risk of disappearance for several reasons: the alteration of hydrological cycles due to climate change, the low success rate of the germination of the seeds of some species and unequal competition with invasive alien species that proliferate both in diversity and quantity [85].

The origin of these species is closely related to their ornamental function, since almost all of them originated in the gardens, having then spread to the natural environment, where they adapted to the 
edaphoclimatic conditions and were able to start an expansion process, occupying the areas in direct competition with native species [86]. Currently, these species grow freely, increasing their area of occupation, often creating groups with other exotic species and native species, as shown in Figure 8.

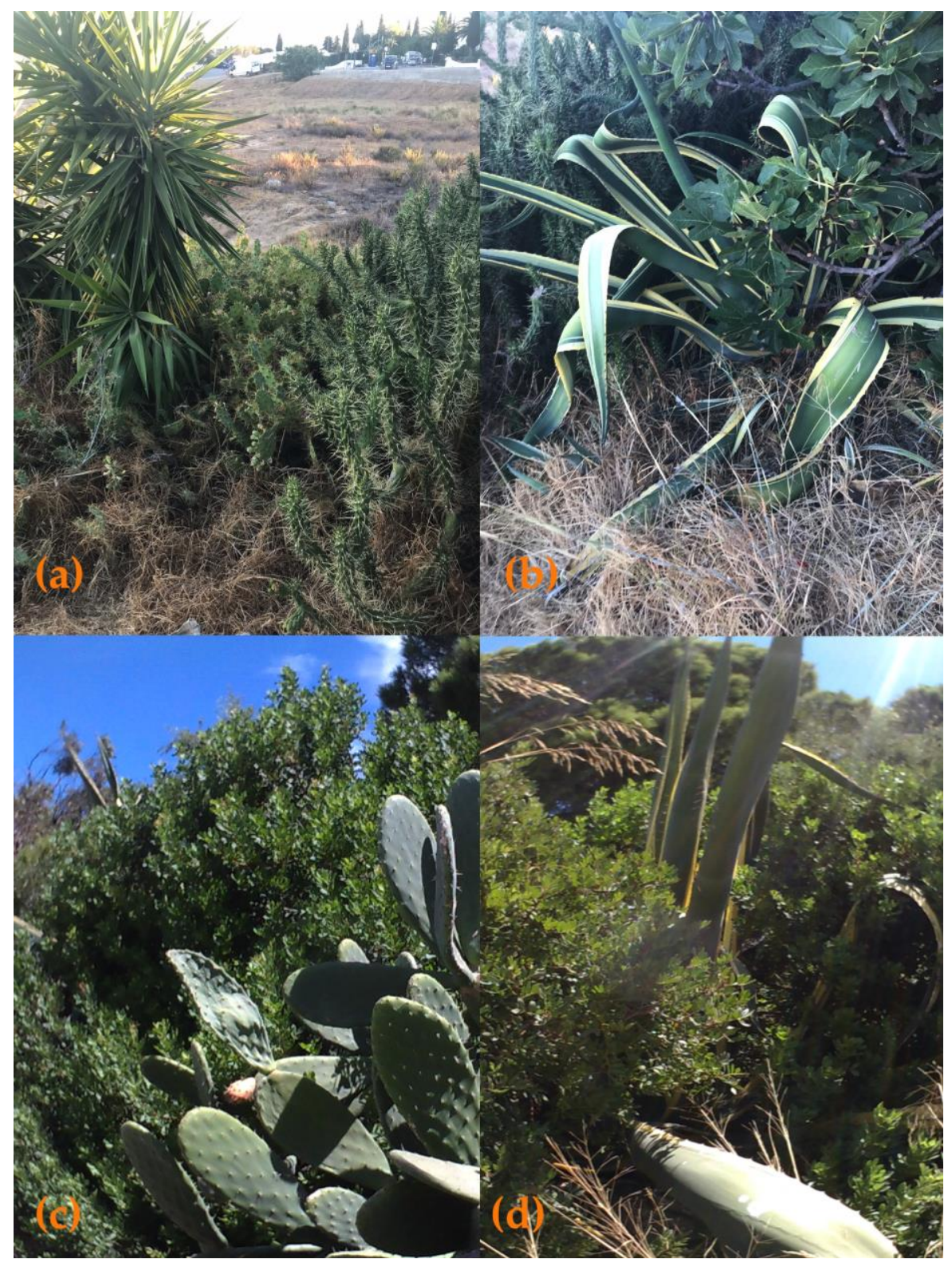

Figure 8. (a) A specimen of Yucca spp. growing together with Cylindropuntia spp. (Engelm.) F. M. Knuth and Opuntia dillenii (Ker Gawl.) Haw.; (b) set of Cylindropuntia spp. (Engelm.) F. M. Knuth, Agave americana L. and Ficus carica L.; (c) specimen of Opuntia ficus-indica (L.) Miller growing in the middle of Rhamnus alaternus L. and (d) Agave americana L. growing among specimens of Rhamnus alaternus L.

\subsection{Artificial Beach Filling}

The beaches in this region and Praia da Cova Redonda consist of well-calibrated, fine and light-colored sands. Over time, the width of the sand decreased until, during high tide, it was practically non-existent and unusable for bathing activities. The rocky bottom was practically in full view, with the sand only a 20-30 m away during the low tide period. This elimination of the sand led the authorities to decide to artificially fill the beach, which occurred during August and September 2014 , as indicated by Teixeira (2016), with the deposition of $67,200 \mathrm{~m}^{3}$ of sand [71]. This met the needs 
of tourism activities. This erosive phenomenon was similar to other beaches in the vicinity: Praia Nova and Praia dos Pescadores.

In the years immediately following the artificial filling of the beaches, there was a period of adaptation of the sediments to the sedimentary dynamics existing in the area. The hydrodynamic calibration of the sediments occurred until an equilibrium was reached, which, although unstable, was maintained. Given the tendency to drift from west to east in the longitudinal direction of the beach, the coarser sandy material was maintained on the west side, while the finer material moved to the east, depositing in the jetty area existing there. Figure 9 compares images of the different granulometry of the sediments.

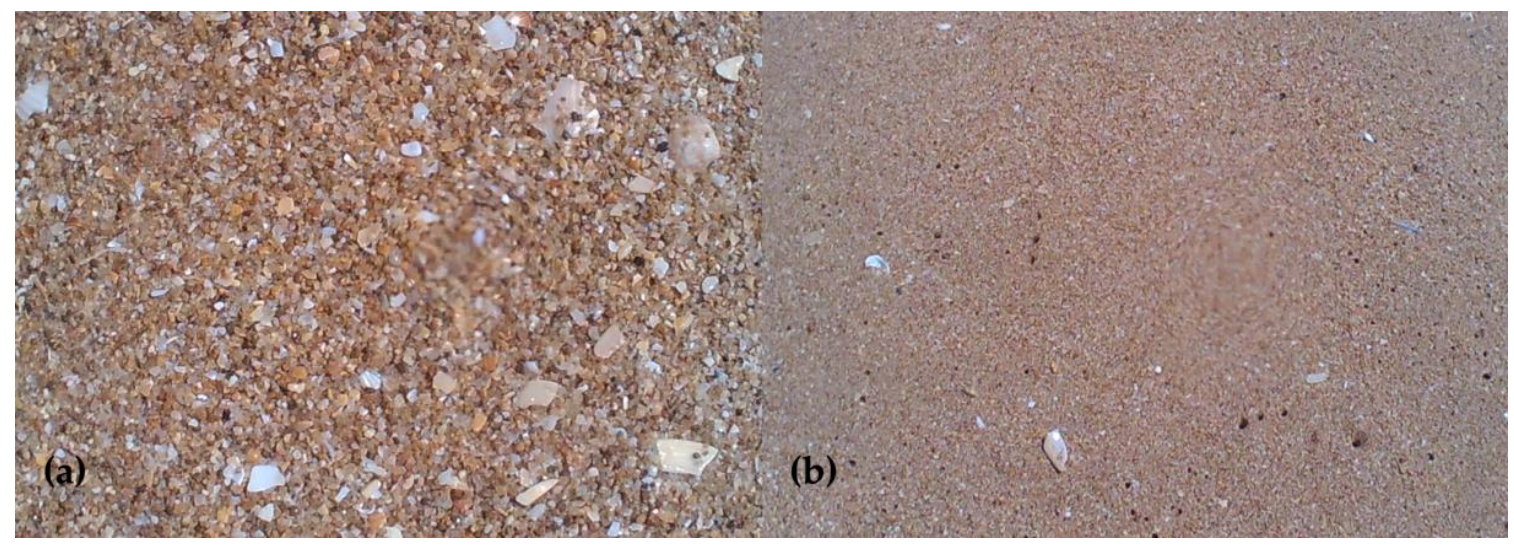

Figure 9. (a) Coarse-grained sediments visible on the west side of Praia da Cova Redonda and (b) fine-grained sediments visible on the east side of Praia da Cova Redonda.

During this three-year adaptation period after the artificial filling of the beach, complaints were often received by users of the beach, mainly by those who had frequented it for dozens of years. The main complaints were due to the quality of the sand, which contained a high percentage of fines that led to the formation of clouds of dust when the wind speed intensified and that continually loaded the sea water with suspended particles, making it difficult to see the bottom, contrary to the previous condition with crystalline waters, one of the hallmarks of the region. Another frequent complaint was related to these sands carrying a high load of shells of various types, which could cause discomfort or injury when walking, since they accumulated in the land-water interface, next to the breaking wave zone.

However, the major negative environmental impact of this artificial beach filling process was the sediment discharge covering an extensive area where many species proliferated. This cover of the seabed by sediments and the subsequent period of adaptation to the new conditions until equilibrium was reached, meant that marine life, which had always been abundant until then, practically disappeared and only slowly reappeared after a few years. Examples of this are the communities of mussels (Mytilus spp. Linnaeus (1758)), limpets (Patella spp. Linnaeus (1758)), barnacles (Chthamalus spp. Ranzani (1817)), anemones (Actinia equina Linnaeus (1758)) and crabs (Pachygrapsus spp. Randall (1839)), which slowly resumed their occupation of the space they had previously inhabited (Figure 10).

After the artificial beach filling the fishes were also slowly returning to the site, as the algae began to recolonize the bottom and the surface of the rocks, making food available for the initial elements of the trophic chains. Shoals of large-scale sand smelt (Atherina boyeri Risso (1810)) were visible, while juvenile specimens of white seabream (Diplodus cadenati de la Paz Bauchot and Daget (1974)), zebra seabream (Diplodus cervinus Lowe (1838)) and black goby (Gobius niger Linnaeus (1758)) could be observed on the rocks, which had disappeared completely in previous years, mainly during the period when the waters were cloudy due to the high amount of fine suspended materials (Figure 11). 


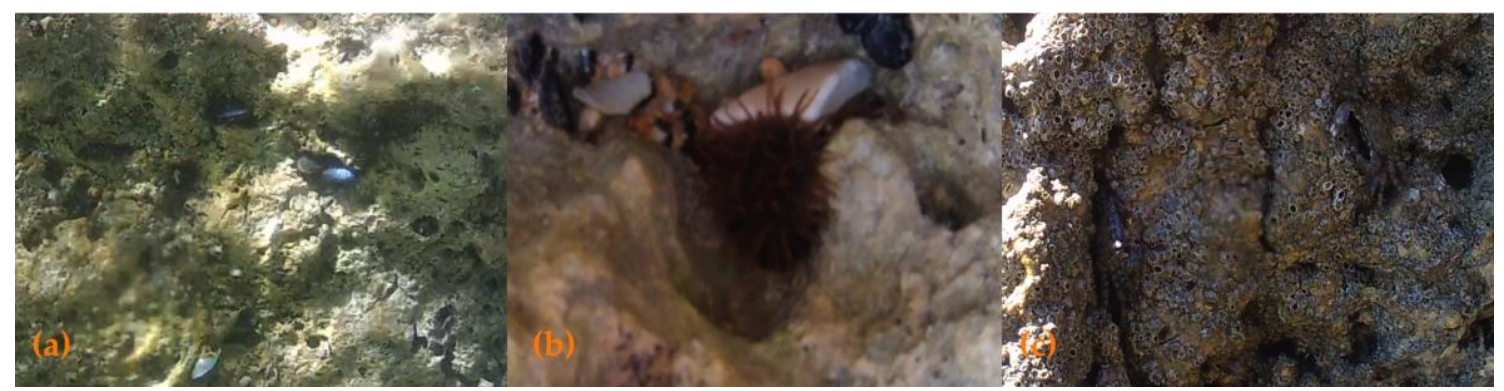

Figure 10. (a) Start of a community of mussels (Mytilus spp. Linnaeus (1758)) on a surface where barnacles (Chthamalus spp. Ranzani (1817)) also abound; (b) anemone specimen (Actinia equina Linnaeus (1758)) and (c) two specimens of crab (Pachygrapsus spp. Randall (1839)) on a surface with barnacles (Chthamalus spp. Ranzani (1817)) and some limpets (Patella spp. Linnaeus (1758)).

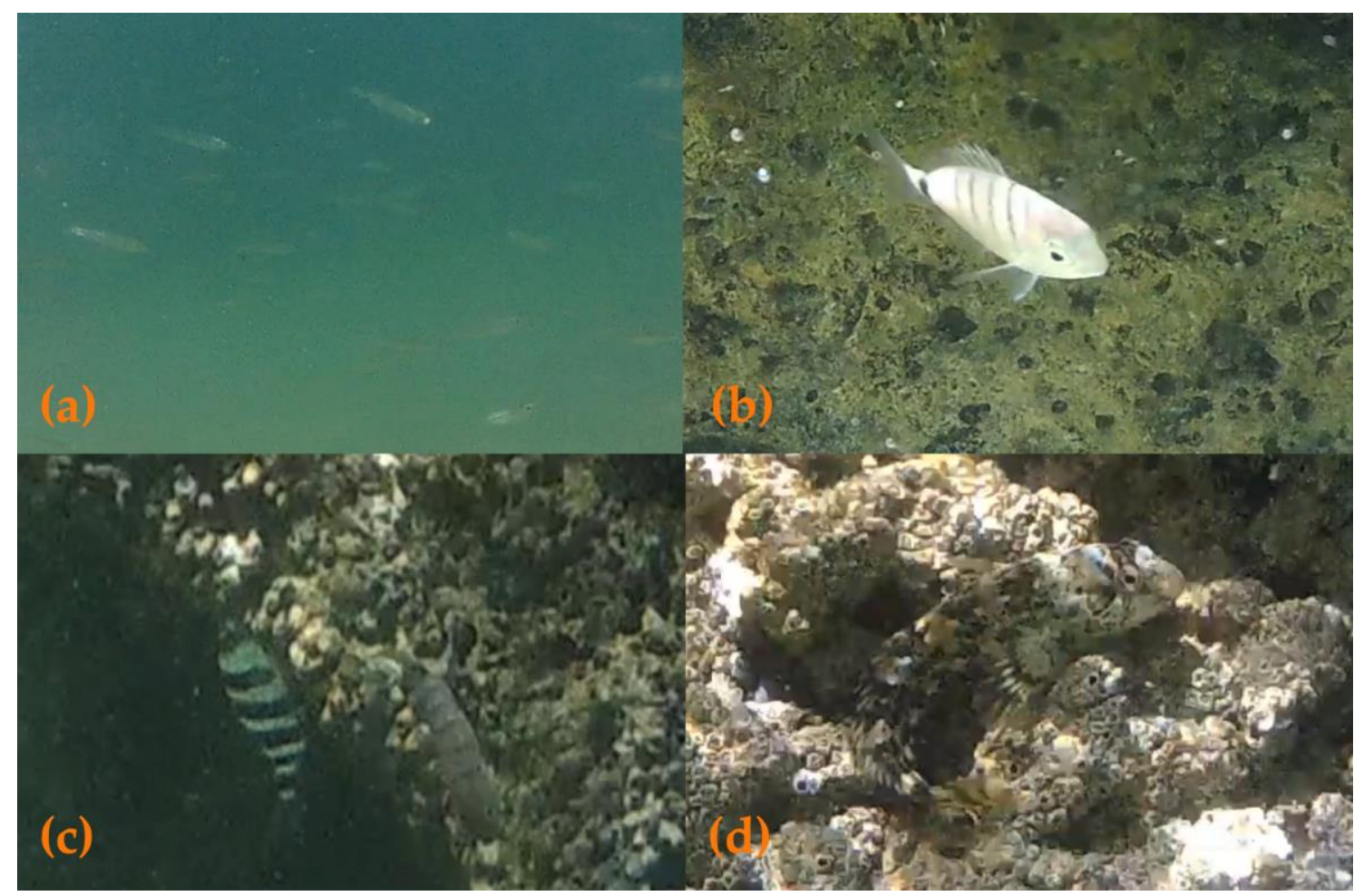

Figure 11. (a) Shoal of big-scale sand smelt (Atherina boyeri Risso (1810)); (b) juvenile specimen of white seabream (Diplodus cadenati de la Paz Bauchot and Daget (1974)); (c) specimen of zebra seabream (Diplodus cervinus Lowe (1838)) feeding near the rocks and (d) a specimen of black goby (Gobius niger Linnaeus (1758)) camouflaged on the rock.

However, although this negative impact on local biodiversity caused by the artificial filling of beaches can be considered to be in the process of being overcome, the potential instability caused by the use of uncalibrated sediments unadjusted to the dynamics of the site can enhance the erosion at the base of the cliffs, caused by the reciprocating movement of the undulation. Given the large amount of solid load suspended in the water, greater abrasion can occur over the soft rocks that make up these cliffs. In this situation, although this is a natural process, the wear of the base of these rock structures may accelerate, thus increasing the risk of fracture of the rock column, posing inherent dangers to users of the beaches (Figures 12 and 13). 
IA

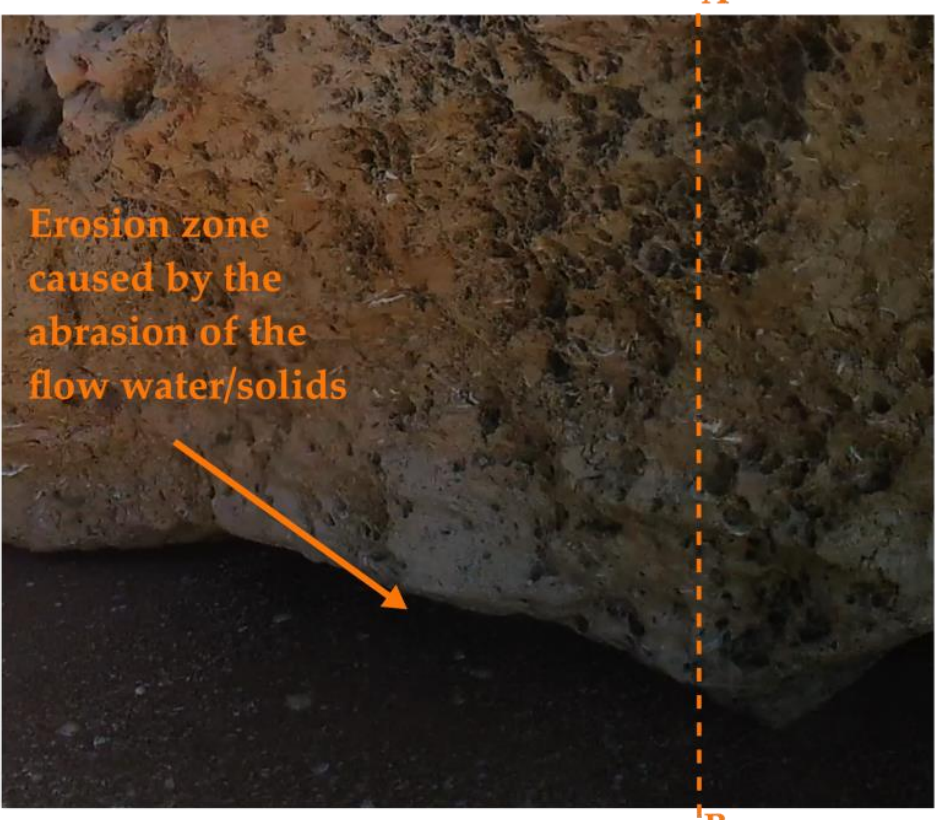

B

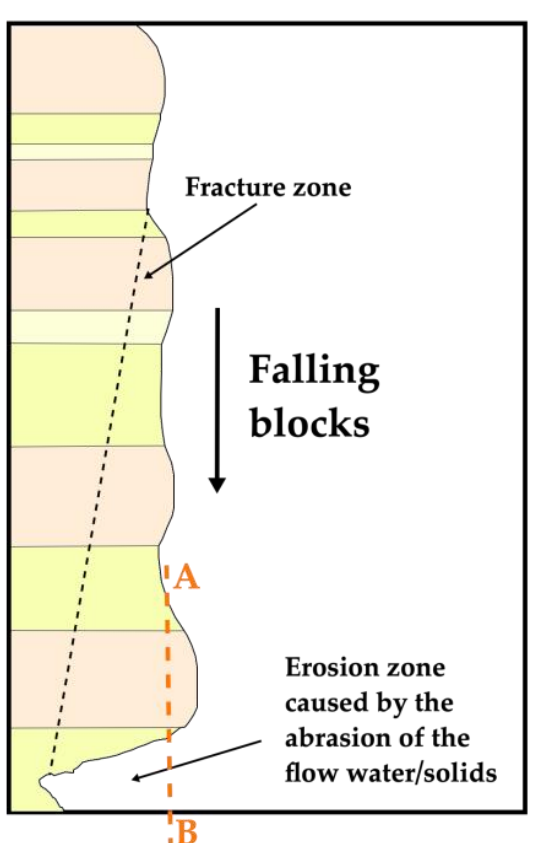

B

Figure 12. Location of the abrasion zone caused by sea undulation with the sediments being dragged against the rocky surface of the cliff, causing mechanical erosion of the rock.

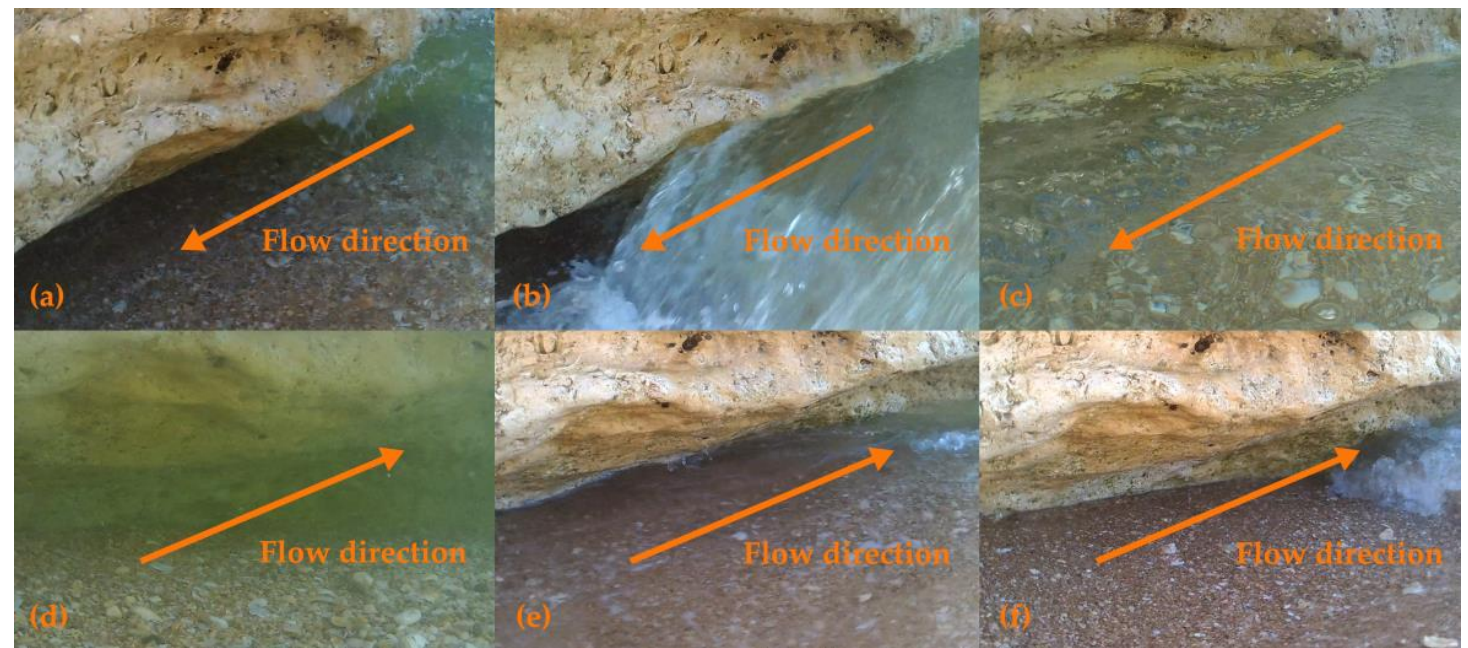

Figure 13. Shuttle flow caused by sea undulation dragging the sediments against the rocky surface causing mechanical erosion. (a) Movement of the wave in increasing approach; (b) Movement of the wave with breaking; (c) Movement of the wave at the maximum point and spreading; (d) Beginning of the return movement of the water body; (e) Maximum sediment dragging period; and (f) Return to the initial position and stabilization until the beginning of a new cycle.

\section{Proposals for Remediation and Mitigation of Negative Impacts}

\subsection{Framework}

The measures presented here were selected and thought to be those that were more in line with the needs and specificities of the location chosen for the present study and, whenever possible, are in line with the measures presented in similar works carried out with the same objective and in equivalent situations. For example, when suggesting the creation of microreserves and small areas of integral protection adjacent to the most affluent beaches, the results obtained in several LIFE projects were 
researched, which also presented the same solution, namely, LIFE 93 NAT/E/000766 "Creation of the micro reserves network and the acquisition of land of priority botanical interest in the Valencian community (1994-1998)", complemented with LIFE 99 NAT/E/006417 "Conservation of priority habitats in the Valencian Community (1999-2003)"; LIFE 99 NAT/IT/006217 "EOLIFE99-Conservation of priority plant species in Aeolian Islands (1999-2004)"; LIFE 00 NAT/E/007355 "Conservation of areas with threatened species in Menorca (2001-2004)"; LIFE 02 NAT/SLO/008587 "Conservation of endangered species/habitats in the future Karst Park (Slovenia) (2002-2005)"; LIFE 04 NAT/GR/000104 "A pilot network of plant micro-reserves in Western Crete (Greece) (2004-2008)"; LIFE 08 NAT/CY/000453 "Establishment of a plant micro-reserve network in Cyprus for the conservation of plant species and habitats (2010-2013)" and LIFE 08 NAT/BG/000279 "A pilot network of small protected sites for plant species in Bulgaria using the plant micro-reserve model (2010-2013)" [87].

The list of measures may not be limited to those presented here; they must be adapted, and others added when justified through adaptation to the circumstances of each specific case. Notably, these types of coastal engineering works are particularly important for certain regions in the country that are grappling with serious coastal erosion problems, causing the disappearance of beaches, and long-term (decadal) assessment should be made whether the project is considered a one-time operation or a series of maintenance operations [88]. This problem is more relevant in regions where tourism represents a large proportion of the economy, such as in Algarve, where the disappearance of beaches in locations that developed because of the interest in the beaches occurred over dozens of years. In other words, the artificial beach filling plays a role in restoring the capacity of a given location to continue to generate income for its inhabitants and therefore have a positive impact that outweighs the negative impacts. However, whenever possible, all measures that allow the minimization and correction of negative impacts should be considered to guarantee sustainable development.

\subsection{Mitigating and Corrective Measures for Negative Impacts Caused by Land Use and Occupation}

The occupation and use of land in the region under study made it difficult to mitigate and/or correct the damage caused, given the use rate that was reached. The area is practically consolidated, with not much more area available for new large-scale projects. However, since the built heritage is already aged, it is likely that requalification projects will be initiated, which may even group several pre-existing properties, giving rise to new infrastructure. In these projects new mitigating and corrective measures must be implemented, including the following:

- Reorganization of the territory and inspection of urban expansion;

- Creation of maximum protection zones that can serve as ecological corridors and;

- Awareness campaigns with property developers for the restoration and protection of natural resources, including landscape resources and biodiversity, e.g., enhancing the use of local flora when planning new gardens or golf fields.

\subsection{Mitigating and Corrective Measures for Negative Impacts Caused by Human Presence, Noise and Pollution}

Of all the negative impacts of the tourism industry, this set is most controversial as it directly interferes with the right to use space and resources. However, this set of impacts can most directly affect the natural resources and simultaneously cause disturbances among the users of the natural spaces. As an example, the noise caused by motorized pleasure boats, which allow enjoyment of the water, can cause discomfort to vacationers who only enjoy the sand and the sea. It is necessary to create a balance between all rights and the damage caused to the resources so that they can be sustained and continue to serve all those concerned. In other words, maintaining the environmental component of a natural ecosystem allows the population to enjoy it from the perspective of leisure and as a source of income, contributing to the economic and social benefits.

The measures presented are as follows: 
- Limitation on the number of users allowed simultaneously on the beach to maintain balance and avoid pressure on the resources. Although not a popular measure, in the 2020 bathing period, due to the restrictions imposed by COVID-19, occupations were much less aggressive, allowing more enjoyment by vacationers;

- Introduction of a fee for the use of the beach to be charged to all users, such as paying for the parking of vehicles in designated areas, and imposing fines for not adhering to parking regulations;

- Limiting the number of visitors to natural places, such as caves or formations, for example, by alternating days of the week for different operators of the vessels who would then have the exclusive access to the places identified as being of interest for visits, while visits by private pleasure boats would be prohibited. In addition to limiting the disturbance caused by an excessive number of visitors, this would allow the ecological fee to be applied to clean beaches and the seabed, protect biodiversity and promote environmental awareness;

- Creation of small-scale integral protection zones in areas adjacent to the most affluent beaches that do not normally have easy access and that would serve as protection zones for different species;

- Environmental awareness and education campaigns aimed at the resident population to demonstrate the advantages of preserving natural resources, even from economic and social points of view and;

- Valuation of good practices associated with waste management, energy efficiency and rational consumption of resources by public and private entities related to the tourism industry, for example, through the creation of standards for the certification of good practices.

\subsection{Mitigating and Corrective Measures for Negative Impacts Caused by the Introduction of Invasive Species}

As previously described, the introduction of invasive alien species is closely related to the species introduced for ornamental and decorative purposes during the creation of garden areas, especially large gardens belonging to tourist resorts or large real estate projects. Later, these species adapted to the edaphoclimatic conditions and began to disperse outside the spaces where they were confined. Currently they are in direct competition for space with native species.

The measures that can be implemented to mitigate or correct the impacts caused by these invasive species on the local indigenous biodiversity include the following:

- Conducting characterization and inventory studies of existing native species, and the characterization and inventory of exotic species already present both in landscaped spaces and in those that have already occupied the natural space;

- Collection of seeds from local ecotypes for conservation in germplasm banks that can be used in environmental recovery projects using native species;

- Approval and inspection of plantation plans to avoid the use of invasive species, applying sanctions when the law is not complied with, namely Decree-Law No. 92/2019, of 10 July, which establishes the legal scheme for the control, custody, introduction into nature and repopulation of exotic species.

- Awareness campaigns for the use of native species in landscape architecture projects to the detriment of exotic species;

- Creation of integral protection zones for native species, with control and eradication of exotic species and;

- Promotion of campaigns to control and eradicate alien species.

\subsection{Mitigating and Corrective Measures for Negative Impacts Caused by Artificial Beach Filling}

The artificial filling of beaches is a coastal engineering task that must be thoroughly considered with arguments of a different nature, such as through a cost-benefit analysis considering all aspects related to the potential returns from the work. As this is complex engineering work that impacts several aspects from changes in sedimentary dynamics, biodiversity, to the safety and comfort of users, 
whenever the decision is made to proceed with this type of technical solution, a set of mitigating measures and correction of the impacts should also be considered.

As main measures for the concrete situation in Praia da Cova Redonda, the following suggestions are provided. Due to the similarity of the situations, the suggestions can be easily transposed to other locations in the same region:

- Conducting studies of sedimentary dynamics and characterization of solid coastal drift flows, and all aspects related to oceanographic data. This measure will make it possible to act in accordance with the knowledge of the study area, facilitating decision-making regarding the best coastal engineering practices, and facilitating the choice of the best-suited materials to be applied on the site with regards to the hydrodynamic conditions of the site;

- Creation of protection zones where the fauna and flora can thrive without disturbances and from where the areas affected by the artificial filling of beaches can be repopulated and;

- Characterization from a floristic point of view to identify threats and pressures affecting the vegetation, which is an essential part of the ecological balance of the beach together with the sedimentary component, in order to plan whether, and where applicable, dune stabilization interventions are necessary with the dual purpose of stopping erosion by restoring and promoting the growth of species.

\section{Conclusions}

The tourism industry is an important aspect of the Portuguese economy and represents the main activity for some regions, including Algarve. No other region in mainland Portugal is as dependent on tourism, so measures must be taken to ensure the region remains desirable for local and international tourists. However, tourism has produced a series of negative impacts that must be analyzed and, whenever possible, mitigated or corrected. From mitigation and correction, the tourist activities can be continuously improved from all perspectives, as presented in the measures recommended here. In other words, all measures that can simultaneously contribute to the mitigation of negative impacts while contributing to the preservation of natural resources should be considered.

Author Contributions: Conceptualization, L.J.R.N., M.A.M.R. and C.J.P.G.; methodology, L.J.R.N., M.A.M.R. and C.J.P.G.; validation, L.J.R.N., M.A.M.R. and C.J.P.G.; investigation, L.J.R.N. and M.A.M.R.; data curation, L.J.R.N., M.A.M.R. and C.J.P.G.; writing — original draft preparation, L.J.R.N. and M.A.M.R.; writing-review and editing, L.J.R.N., M.A.M.R. and C.J.P.G.; supervision, L.J.R.N., M.A.M.R. and C.J.P.G.; project administration, L.J.R.N., M.A.M.R. and C.J.P.G. All authors have read and agreed to the published version of the manuscript.

Funding: This research received no external funding.

Acknowledgments: The authors declare no further acknowledgements.

Conflicts of Interest: The authors declare no conflict of interest.

\section{References}

1. Steiger, R.; Scott, D. Ski tourism in a warmer world: Increased adaptation and regional economic impacts in Austria. Tour. Manag. 2020, 77, 104032. [CrossRef]

2. Kimbu, A.N.; Tichaawa, T.M. Sustainable development goals and socio-economic development through tourism in Central Africa: Myth or reality? GeoJ. Tour. Geosites 2018, 23, 780-796.

3. Gössling, S.; Scott, D.; Hall, C.M. Pandemics, tourism and global change: A rapid assessment of COVID-19. J. Sustain. Tour. 2020, 1-20. [CrossRef]

4. Higgins-Desbiolles, F. Socialising tourism for social and ecological justice after COVID-19. Tour. Geogr. 2020, 22, 1-14. [CrossRef]

5. Niewiadomski, P. COVID-19: From temporary de-globalisation to a re-discovery of tourism? Tour. Geogr. 2020, 22, 1-6. [CrossRef]

6. Correa-Martínez, C.L.; Kampmeier, S.; Kümpers, P.; Schwierzeck, V.; Hennies, M.; Hafezi, W.; Kühn, J.; Pavenstädt, H.; Ludwig, S.; Mellmann, A. A pandemic in times of global tourism: Superspreading and exportation of COVID-19 cases from a ski area in Austria. J. Clin. Microbiol. 2020, 58, e00588-20. 
7. Prideaux, B.; Thompson, M.; Pabel, A. Lessons from COVID-19 can prepare global tourism for the economic transformation needed to combat climate change. Tour. Geogr. 2020, 22, 1-12. [CrossRef]

8. Evans, S.; Vladimirova, D.; Holgado, M.; Van Fossen, K.; Yang, M.; Silva, E.A.; Barlow, C.Y. Business model innovation for sustainability: Towards a unified perspective for creation of sustainable business models. Bus. Strategy Environ. 2017, 26, 597-608. [CrossRef]

9. Abdel-Shafy, H.I.; Mansour, M.S. Solid waste issue: Sources, composition, disposal, recycling, and valorization. Egypt. J. Pet. 2018, 27, 1275-1290. [CrossRef]

10. Pavithra, K.G.; Jaikumar, V. Removal of colorants from wastewater: A review on sources and treatment strategies. J. Ind. Eng. Chem. 2019, 75, 1-19. [CrossRef]

11. Sahin, E.S.; Bayram, I.S.; Koc, M. Demand side management opportunities, framework, and implications for sustainable development in resource-rich countries: Case study Qatar. J. Clean. Prod. 2019, 241, 118332. [CrossRef]

12. Büscher, B.; Fletcher, R. Destructive creation: Capital accumulation and the structural violence of tourism. J. Sustain. Tour. 2017, 25, 651-667. [CrossRef]

13. Jover, J.; Díaz-Parra, I. Who is the city for? Overtourism, lifestyle migration and social sustainability. Tour. Geogr. 2020, 1-24. [CrossRef]

14. Chamekh, M. The interplay of health, pleasure and wellness in British Seaside Resorts: The case of skegness on the Lincolnshire Coast. Revue Française de Civilisation Britannique. Fr. J. Br. Stud. 2019, 24. [CrossRef]

15. Durie, A.J. A fading movement: Hydropathy at the Scottish hydros 1840-1939. J. Tour. Hist. 2012, 4, 57-74. [CrossRef]

16. Hampton, M.P.; Jeyacheya, J.; Long, P.H. Can tourism promote inclusive growth? Supply chains, ownership and employment in Ha Long Bay, Vietnam. J. Dev. Stud. 2018, 54, 359-376. [CrossRef]

17. MacNeill, T.; Wozniak, D. The economic, social, and environmental impacts of cruise tourism. Tour. Manag. 2018, 66, 387-404. [CrossRef]

18. Michailidou, A.V.; Vlachokostas, C.; Moussiopoulos, N.; Maleka, D. Life cycle thinking used for assessing the environmental impacts of tourism activity for a Greek tourism destination. J. Clean. Prod. 2016, 111, 499-510. [CrossRef]

19. Lee, J.W.; Syah, A.M. Economic and environmental impacts of mass tourism on regional tourism destinations in Indonesia. J. Asian Financ. Econ. Bus. 2018, 5, 31-41. [CrossRef]

20. Hiltunen, M.J.; Pitkänen, K.; Halseth, G. Environmental perceptions of second home tourism impacts in Finland. Local Environ. 2016, 21, 1198-1214. [CrossRef]

21. Rutty, M.; Scott, D.; Matthews, L.; Burrowes, R.; Trotman, A.; Mahon, R.; Charles, A. An inter-comparison of the Holiday Climate Index (HCI: Beach) and the Tourism Climate Index (TCI) to explain Canadian tourism arrivals to the Caribbean. Atmosphere 2020, 11, 412. [CrossRef]

22. Enríquez, A.R.; Bestard, A.B. Measuring the economic impact of climate-induced environmental changes on sun-and-beach tourism. Clim. Chang. 2020, 160, 1-15. [CrossRef]

23. Kasmi, S.; Snoussi, M.; Khalfaoui, O.; Aitali, R.; Flayou, L. Increasing pressures, eroding beaches and climate change in Morocco. J. Afr. Earth Sci. 2020, 164, 103796. [CrossRef]

24. Rizzetto, F. Effects of climate change on the morphological stability of the Mediterranean Coasts: Consequences for tourism. In Climate Change, Hazards and Adaptation Options; Springer: Berlin/Heidelberg, Germany, 2020; pp. 761-775.

25. Farinha, F.; Oliveira, M.J.; Silva, E.M.; Lança, R.; Pinheiro, M.D.; Miguel, C. Selection process of sustainable indicators for the Algarve region-Observe project. Sustainability 2019, 11, 444. [CrossRef]

26. Soler, I.P.; Gemar, G.; Correia, M.B.; Serra, F. Algarve hotel price determinants: A hedonic pricing model. Tour. Manag. 2019, 70, 311-321. [CrossRef]

27. Oliveira, M.J.; Farinha, F.; da Silva, E.M.; Lança, R.; Pinheiro, M.D.; Miguel, C. Observatory of sustainability of the Algarve Region for tourism: Proposal for environmental and sociocultural indicators. Int. J. Humanit. Soc. Sci. 2019, 13, 1237-1244.

28. de Freitas, J.G.; Dias, J.A. Governance and management of Coastal Zones. Algarve (Portugal): A historical view of the impacts of seaside tourism. Glob. Environ. 2019, 12, 375-403. [CrossRef]

29. Ramos, M.J.; Medeiros, A.; Praça, G.; Sena, P. Managing natural resources in Eastern Algarve, Portugal: An assessment of the policy uses of local knowledge (s). In Negotiating Local Knowledge: Power and Identity in Development; Pottier, J., Bicker, A., Sillitoe, P., Eds.; Pluto Press: London, UK, 2003; pp. 155-170. 
30. de Noronha Vaz, E.; Walczynska, A.; Nijkamp, P. Regional challenges in tourist wetland systems: An integrated approach to the Ria Formosa in the Algarve, Portugal. Reg. Environ. Chang. 2013, 13, 33-42. [CrossRef]

31. Seabra, C.; Silva, C.; Abrantes, J.L. Place-attachment and involvement by tourists of natural areas. Tour. Manag. Stud. 2011, 2, 1105-1108.

32. Sannigrahi, S.; Joshi, P.K.; Keesstra, S.; Paul, S.K.; Sen, S.; Roy, P.; Chakraborti, S.; Bhatt, S. Evaluating landscape capacity to provide spatially explicit valued ecosystem services for sustainable coastal resource management. Ocean Coast. Manag. 2019, 182, 104918. [CrossRef]

33. Pinto, C.A.; Silveira, T.M.; Teixeira, S.B. Beach nourishment practice in mainland Portugal (1950-2017): Overview and retrospective. Ocean Coast. Manag. 2020, 192, 105211. [CrossRef]

34. Teixeira, S.B. A alimentação artificial como medida de redução do risco em praias suportadas por arribas rochosas na costa do Barlavento (Algarve, Portugal). Rev. Gestão Costeira Integr. J. Integr. Coast. Zone Manag. 2016, 16, 327-342. [CrossRef]

35. Carapeto, A. New records of alien vascular plant species in mainland Portugal. Novos registos de plantas vasculares exóticas em Portugal continental. Acta Bot. Malacit. 2016, 41, 281-286. [CrossRef]

36. Campoy, J.G.; Acosta, A.T.; Affre, L.; Barreiro, R.; Brundu, G.; Buisson, E.; González, L.; Lema, M.; Novoa, A.; Retuerto, R. Monographs of invasive plants in Europe: Carpobrotus. Bot. Lett. 2018, 165, 440-475. [CrossRef]

37. Brunel, S.; Schrader, G.; Brundu, G.; Fried, G. Emerging invasive alien plants for the Mediterranean Basin. EPPO Bull. 2010, 40, 219-238. [CrossRef]

38. Marchante, H.; Morais, M.; Freitas, H.; Marchante, E. Guia Prático para a Identificação de Plantas Invasoras em Portugal; Imprensa da Universidade de Coimbra/Coimbra University Press: Coimbra, Portugal, 2014.

39. Russo, M.; Relvas, H.; Gama, C.; Lopes, M.; Borrego, C.; Rodrigues, V.; Robaina, M.; Madaleno, M.; Carneiro, M.; Eusébio, C. Estimating emissions from tourism activities. Atmos. Environ. 2020, 220, 117048. [CrossRef]

40. Varelas, S.; Kopanaki, E.; Georgopoulos, N. A strategic tourism knowledge base for socio-economic and environmental data analytics: The role of Big Data analysis. Zesz. Nauk. Małopolskiej Wyższej Szkoły Ekon. Tarn. 2020, 45, 69-76.

41. Sousa, C.A.; Cunha, M.E.; Ribeiro, L. Tracking 130 years of coastal wetland reclamation in Ria Formosa, Portugal: Opportunities for conservation and aquaculture. Land Use Policy 2020, 94, 104544. [CrossRef]

42. Bienvenido-Huertas, D.; Farinha, F.; Oliveira, M.J.; Silva, E.M.; Lança, R. Challenge for planning by using cluster methodology: The case study of the Algarve Region. Sustainability 2020, 12, 1536. [CrossRef]

43. Sá Marques, T.; Saraiva, M.; Ribeiro, D.; Amante, A.; Silva, D.; Melo, P. Accessibility to services of general interest in polycentric urban system planning: The case of Portugal. Eur. Plan. Stud. 2020, 28, 1068-1094. [CrossRef]

44. Cavaco, C.; Costa, J.P. Administrative organisation and spatial planning in Portugal: A push towards soft planning spaces in Europe? In Shaping Regional Futures; Springer: Berlin/Heidelberg, Germany, 2020; pp. 87-101.

45. Raschke, N. Environmental impact assessment as a step to sustainable tourism development. WIT Trans. Ecol. Environ. 1970, 84. [CrossRef]

46. Yusoff, S.; Hashim, R. A case study on an Environmental Impact Assessment in Malaysia. WIT Trans. Ecol. Environ. 1970, 17. [CrossRef]

47. Haulot, A.; Vanhove, N.; Verheyden, L.; Charlier, R. Coastal belt tourism, economic development and environmental impact. Int. J. Environ. Stud. 1977, 10, 161-172. [CrossRef]

48. Inskeep, E. Environmental planning for tourism. Ann. Tour. Res. 1987, 14, 118-135. [CrossRef]

49. Travis, A.S. Managing the environmental and cultural impacts of tourism and leisure development. Tour. Manag. 1982, 3, 256-262. [CrossRef]

50. Romeril, M. Tourism-the environmental dimension. Prog. Tour. Recreat. Hosp. Manag. 1989, 1, $103-113$.

51. Liu, J.C.; Var, T. Resident attitudes toward tourism impacts in Hawaii. Ann. Tour. Res. 1986, 13, $193-214$. [CrossRef]

52. Holder, J.S. Pattern and impact of tourism on the environment of the Caribbean. Tour. Manag. 1988, 9, 119-127. [CrossRef]

53. Sun, D.; Walsh, D. Review of studies on environmental impacts of recreation and tourism in Australia. J. Environ. Manag. 1998, 53, 323-338. [CrossRef] 
54. Canteiro, M.; Córdova-Tapia, F.; Brazeiro, A. Tourism impact assessment: A tool to evaluate the environmental impacts of touristic activities in Natural Protected Areas. Tour. Manag. Perspect. 2018, 28, 220-227. [CrossRef]

55. Ellison, J.C. Pacific island beaches: Values, threats and rehabilitation. In Beach Management Tools-Concepts, Methodologies and Case Studies; Springer: Berlin/Heidelberg, Germany, 2018; pp. 679-700.

56. Setyaningrum, E.; Dewi, A.; Prapti, K.; Erwanto, Z.; Susanti, H. Area development based on conservation and ecotourism on the Cemara Beach (Pine Trees Beach), Pakis, Banyuwangi, East Java Province, Indonesia. EEES 2019, 236, 012132.

57. Costa, L.L.; Zalmon, I.R. Sensitivity of macroinvertebrates to human impacts on sandy beaches: A case study with tiger beetles (Insecta, Cicindelidae). Estuar. Coast. Shelf Sci. 2019, 220, 142-151. [CrossRef]

58. da Costa Cristiano, S.; Rockett, G.C.; Portz, L.C.; de Souza Filho, J.R. Beach landscape management as a sustainable tourism resource in Fernando de Noronha Island (Brazil). Mar. Pollut. Bull. 2020, 150, 110621. [CrossRef] [PubMed]

59. Mateus, M.; Almeida, D.; Simonson, W.; Felgueiras, M.; Banza, P.; Batty, L. Conflictive uses of coastal areas: A case study in a southern European coastal lagoon (Ria de Alvor, Portugal). Ocean Coast. Manag. 2016, 132, 90-100. [CrossRef]

60. Harik, G.; Alameddine, I.; Maroun, R.; Rachid, G.; Bruschi, D.; Garcia, D.A.; El-Fadel, M. Implications of adopting a biodiversity-based vulnerability index versus a shoreline environmental sensitivity index on management and policy planning along coastal areas. J. Environ. Manag. 2017, 187, 187-200. [CrossRef] [PubMed]

61. Cavallaro, F.; Galati, O.I.; Nocera, S. Policy strategies for the mitigation of GHG emissions caused by the mass-tourism mobility in coastal areas. Transp. Res. Procedia 2017, 27, 317-324. [CrossRef]

62. Kovačić, M.; Silveira, L. Cruise tourism: Implications and impacts on the destinations of Croatia and Portugal. Pomorstvo 2020, 34, 40-47. [CrossRef]

63. Pereira, L.N.; Santos, M.C.; Ferreira, L.N. Tourism stakeholders' perceptions on global trends in coastal areas of the Mediterranean region. Int. J. Tour. Policy 2020, 10, 23-46. [CrossRef]

64. Rebelo, E.M.; Graça, R.; Martins, F. Vulnerability Identity (V. ID) for the Algarve coastal municipalities subjected to coastal oil spill accidents. In Proceedings of the ICUR2016-International Conference on Urban Risks, Lisabon, Portugal, 30 June-2 July 2016.

65. Blau, M.L.; Luz, F.; Panagopoulos, T. Urban river recovery inspired by nature-based solutions and biophilic design in Albufeira, Portugal. Land 2018, 7, 141. [CrossRef]

66. Pallero, C.; Barragán, J.; Scherer, M. Management international estuarine systems: The case of the Guadiana river (Spain-Portugal). Environ. Sci. Policy 2018, 80, 82-94. [CrossRef]

67. Dogru, T.; Marchio, E.A.; Bulut, U.; Suess, C. Climate change: Vulnerability and resilience of tourism and the entire economy. Tour. Manag. 2019, 72, 292-305.

68. Scott, D.; Hall, C.M.; Gössling, S. Global tourism vulnerability to climate change. Ann. Tour. Res. 2019, 77, 49-61.

69. Friedrich, J.; Stahl, J.; Fitchett, J.; Hoogendoorn, G. To beach or not to beach? Socio-economic factors influencing beach tourists' perceptions of climate and weather in South Africa. Trans. R. Soc. S. Afr. 2020, 75, 1-9.

70. Rivas-Martínez, S.; Penas, Á.; del Río, S.; González, T.E.D.; Rivas-Sáenz, S. Bioclimatology of the Iberian Peninsula and the Balearic Islands. In The Vegetation of the Iberian Peninsula; Springer: Berlin/Heidelberg, Germany, 2017; pp. 29-80.

71. Veloso-Gomes, F.; Costa, J.; Rodrigues, A.; Taveira-Pinto, F.; Pais-Barbosa, J.; Neves, L.D. Costa da Caparica artificial sand nourishment and coastal dynamics. J. Coast. Res. 2009, 56, 678-682.

72. Armenteros, I.; Dabrio, C.J.; Legoinha, P.; González-Delgado, J.; Martínez-Graña, A.; Alonso-Gavilán, G.; Civis, J.; Pais, J. Facies and sequence analysis of Miocene open-shelf warm-temperate carbonates in Portimão (Lagos-Portimão Formation, Portugal). Facies 2019, 65, 33.

73. Chester, D.K. Pleistocene and Holocene geomorphological development in the Algarve, southern Portugal. Geomorphology 2012, 153, 17-28.

74. Raposo, M.; Conceição-Castro, M.; Gomes, C.P. The application of symphytosociology in landscape architecture. Botanique 2016, 1, 103-112.

75. Raposo, M.; Mendes, P.; Cano-Ortiz, A.; Pinto-Gomes, C. Séries de vegetação prioritárias para a conservação no centro e sul de Portugal continental. Botanique 2016, 1, 113-148. 
76. Whitfield, A.; Becker, A. Impacts of recreational motorboats on fishes: A review. Mar. Pollut. Bull. 2014, 83, 24-31.

77. Sim, V.X.; Dafforn, K.A.; Simpson, S.L.; Kelaher, B.P.; Johnston, E.L. Sediment contaminants and infauna associated with recreational boating structures in a multi-use marine park. PLoS ONE 2015, 10, e0130537.

78. Islam, M.S.; Tanaka, M. Impacts of pollution on coastal and marine ecosystems including coastal and marine fisheries and approach for management: A review and synthesis. Mar. Pollut. Bull. 2004, 48, 624-649. [CrossRef]

79. Burgin, S.; Hardiman, N. The direct physical, chemical and biotic impacts on Australian coastal waters due to recreational boating. Biodivers. Conserv. 2011, 20, 683-701. [CrossRef]

80. Eriksson, B.K.; Sandström, A.; Isæus, M.; Schreiber, H.; Karås, P. Effects of boating activities on aquatic vegetation in the Stockholm archipelago, Baltic Sea. Estuar. Coast. Shelf Sci. 2004, 61, 339-349. [CrossRef]

81. Sundblad, G.; Bergström, U. Shoreline development and degradation of coastal fish reproduction habitats. Ambio 2014, 43, 1020-1028. [CrossRef]

82. Maxwell, R.J.; Zolderdo, A.J.; de Bruijn, R.; Brownscombe, J.W.; Staaterman, E.; Gallagher, A.J.; Cooke, S.J. Does motor noise from recreational boats alter parental care behaviour of a nesting freshwater fish? Aquat. Conserv. Mar. Freshw. Ecosyst. 2018, 28, 969-978. [CrossRef]

83. Hawkins, A.D.; Pembroke, A.E.; Popper, A.N. Information gaps in understanding the effects of noise on fishes and invertebrates. Rev. Fish Biol. Fish. 2015, 25, 39-64. [CrossRef]

84. Zoomers, A.; Van Noorloos, F.; Otsuki, K.; Steel, G.; Van Westen, G. The rush for land in an urbanizing world: From land grabbing toward developing safe, resilient, and sustainable cities and landscapes. World Dev. 2017, 92, 242-252. [CrossRef]

85. Fischer, A.; Marshall, P.; Camp, A. Disturbances in deciduous temperate forest ecosystems of the northern hemisphere: Their effects on both recent and future forest development. Biodivers. Conserv. 2013, 22, 1863-1893. [CrossRef]

86. Reichard, S.H.; White, P. Horticulture as a pathway of invasive plant introductions in the United States: Most invasive plants have been introduced for horticultural use by nurseries, botanical gardens, and individuals. BioScience 2001, 51, 103-113. [CrossRef]

87. Laguna, E.; Ballester, G.; Deltoro, V. Plant Micro-Reserves (PMRs): Origin and technical concept. In Plant Micro-Reserve: From Theory to Practice, Experiences Gained from EU LIFE and Other Related Projects; Utopia: Athens, Greece, 2013; pp. 2-12.

88. Nordstrom, K. Beach nourishment and coastal habitats: Research needs to improve compatibility. Restor. Ecol. 2005, 13, 215-222. [CrossRef]

(C) 2020 by the authors. Licensee MDPI, Basel, Switzerland. This article is an open access article distributed under the terms and conditions of the Creative Commons Attribution (CC BY) license (http://creativecommons.org/licenses/by/4.0/). 